DOI $10.31489 / 2020 \mathrm{Ec} 3 / 40-48$

JEL M 31

UDC 338.48

\author{
A.S. Kenebayeva ${ }^{1, *}$, A.I. Nurmagambetova ${ }^{2}$ \\ ${ }^{1}$ Research Institute for Social \& Gender Studies, \\ Kazakh National Women's Teacher Training University, Kazakhstan \\ ${ }^{2}$ Center for Entrepreneurship CACTLE, L.N. Gumilyov Eurasian National University, Kazakhstan \\ Iainur88ainur@gmail.com, 2arnurcom@gmail.com \\ ${ }^{1}$ http://orcid.org/0000-0002-9222-4364, ${ }^{2}$ http://orcid.org/0000-0002-3731-3970 \\ ${ }^{1}$ Scopus Author ID: 56112489300, ${ }^{1}$ Researcher ID: AAW-3493-2020
}

\title{
Attitudes of Kazakhstani consumers towards experiential hospitality and tourism services
}

\section{Abstract}

Object: This paper aims to addresses new transformations in customer experience concept form a hospitality perspective. In particular, it studies the attitudes and perceptions of consumers towards the implementation of new experiential offerings in hotel and restaurant sectors on an example of Kazakhstan.

Methods: This research adopts the quantitative research methods with a survey data collection technique. The initial data have been collected by a self administered questionnaire with five point Likert scales and fixed-choice questions to measure attitudes of consumers. This quantitative empirical study applied a probability sampling method and involved random distribution technique. The total sample size was 300 respondents.

Findings: Findings indicate that local consumers have a positive attitude toward new service concepts and experiential hospitality offerings such as "soap/fragrance butler", "futuristic hotels" and "interactive menu". However, Kazakhstani consumers prefer direct live communications with service personnel more than interactions with robots and demonstrate relatively negative attitude towards service automation.

Conclusions: The research shows that local hospitality and tourism market is ready for service innovations. Designing customer-oriented experiences can be an integral part of competitive strategies of hospitality companies and helps to find unique ways to attract modern customer segments.

Keywords: consumer behavior, customer attitudes, consumer preferences, customer experience, services marketing, service quality, hospitality and tourism industry.

\section{Introduction}

Nowadays customer oriented modern companies operating mainly in service sectors are developing a range of experiential marketing strategies, including various incentives that affect a consumer at points of interaction with the company. These incentives may include a traditional or advanced marketing mix. Experiential marketing is used to attract consumers to interact with a company, services or products by increasing consumer engagement through positive emotions. This strategy is specifically designed to ensure that customers receive positive memorable emotions through direct or indirect contact with the company (Gopalani $\&$ Shick, 2011). The interaction and the creation of a "unique experience" can take place in three stages: preconsumption, actual and subsequent consumption.

Studying the evolutionary stages of the "customer experience" concept shows that the technology of personalizing any economic offers will gradually go beyond the "experience economy", the theoretical basis of which was laid by J. Pine and J. Gilmore (Pine \& Gilmore, 1998). The development of customer-oriented strategies aimed at creating customer experience has generated a new set of standards, which in turn affects customer expectations. These changes have formed a consumer market that values responsible business practices, which modern companies are trying to reflect through value systems, quality management, and customer oriented corporate cultures. Meanwhile, advanced technologies and ubiquitous access to information leads to a change in the model of relationships between companies and modern consumers. The hospitality industry is turning to technology to meet the challenge of growing customer expectations. Technological innovations, advanced software products, information and communication systems as well as robotics are increasingly used in tourism and hospitality related sectors to improve efficiency of technological operations and service quality (Koutroumanis, 2011). And although the vast majority of businesses are currently seeking for a competitive advantage and trying to create a unique experience for their clients, proactive compa-

\footnotetext{
* Corresponding author.

E-mail address: ainur88ainur@gmail.com
} 
nies are already beginning to build a new strategy, responding to predicted changes in consumer behaviour (Lindgreen, Vanhamme, J. \& Beverland, 2012).

In this regard, this study aims to examine attitudes and perceptions of customers on a unique consumer experience in the Kazakhstani hotel and restaurant service sector. From a conceptual perspective the research focuses on an evaluation of a customer experience strategy briefly discussing modern transformations and shifts from traditional approaches to new differentiation strategies. From a practical side this study represents preliminary data describing changes in consumer behaviour. Furthermore, this study expands understanding of the experience economy and fills a contextual gap by examining consumer attitudes on an example of Kazakh service industry. This research in general seeks to provide an insight into changes in consumer attitudes and behaviour within the new experiences-mediated service environment. On the other hand, the study contributes to the body of knowledge by focusing on consumers' attitudes towards the potential application of hospitality and tourism experiences in emerging economies. This research representing Kazakhstani context gives an insight into Central Asian emerging markets and contributes to a theoretical gap in the literature. Although there are a growing number of publications investigating the effect of customer experiences on attitudes and behaviours, majority of prior works are fragmented by a very specific types of experiences, and therefore do not able to give a complex understanding about consumer attitudes towards various offerings. This paper integrates various forms of experiences ("soap butler", "interactive menu", "robotics", "futuristic and virtual environment") including simple offerings as well as sophisticated technological services and provides holistic knowledge on this issue.

\section{Literature Review}

As indicated by previous studies, modern consumers of hospitality and tourism services are becoming more self-indulgent and increasingly demanding highly personalized extraordinary customer treatment technologies (Bharwani \& Jauhari, 2013; Van Boven \& Gilovich, 2003; Erdly and Kesterson-Townes, 2003). Although the service quality and customer satisfaction concepts have been sufficiently highlighted in hospitality and tourism literature, transformational changes in customer service experiences have been relatively overlooked (Chen \& Chen, 2010). Service experience are usually defined as a set of fillings and emotions emerging as a result of direct or indirect contact with a company and consequently effecting customer satisfaction (Meyer \& Schwager, 2007). The modern strategy of consumer experience will be fully focused on human relations, where the value will be more significant and more important than profit. This requires companies to strengthen emotional ties that will go beyond traditional consumer needs. The next stage in the evolutionary process of the "customer experience" concept will be the "human experience" - a new approach to differentiation and growth strategies (Sparks, 2015).

Experts in the field of marketing identify three fundamentals in the evolution of consumer experience, gradually moving into the "human experience":

1) Transparency. Each action of the company, its corporate values becomes publicly accessible under the influence of advanced technologies and the popularity of social networks. Modern consumers trust and value companies that share their values, actively providing reliable information about themselves and about their actions in the market.

2) Consumer experience that goes beyond customer interaction. Advanced technology has turned companies into brand ambassadors. This means that anyone who tells the story of a brand or company is now a part of consumer experience. Companies use their brand as a client-oriented strategy allowing customers, employees and partners collectively create the history of a company or its brand, guided by their personal experience.

3) Substantial consumer experience exceeds basic needs. The development of new technologies in combination with modern customer-oriented strategies allows companies to understand the individual characteristics of customers and improve the service process. Successful companies go beyond traditional needs and try to understand and meet human needs, such as freedom, individuality, and creativity. Companies that recognize value and human needs, in addition to meeting functional needs, are able to provide unforgettable, meaningful impressive and memorable experiences that create benefits and value not only for customers, but also for their employees and business partners.

Positive consumer experience is recognized as an important factor influencing consumer behaviour, including satisfaction and customer loyalty (Becker \& Jaakkola, 2020). The hospitality industry is considered as one of the most customer-focused sectors in which customer experience is applied very intensively. The development and provision of a unique consumer experience plays an important role in differentiating hotel 
or restaurant services. Tech-savvy modern consumers expect product personalization and an individual service at each stage of interaction with a company. According to expert studies, 89 percent of firms expect to compete primarily on the basis of consumer experience, and now this is one of the key strategies used by companies in the hotel and restaurant business. Leading companies in the global hospitality industry, such as Marriott, Hilton, Starwood, Starbucks, Disney keep ahead the competitors mainly due to the creation of a unique consumer experience both offline and online (Kandampully, Zhang \& Jaakkola, 2017).

Ensuring a high level of satisfaction and loyalty requires a deep understanding of the main components of consumer experience, which in turn determines the importance of studying and analyzing the perceptions of potential consumers (Cetin \& Walls, 2015). Clients and managers may perceive consumer experience in different ways. Studies related to discrepancies between the perception of the consumer and the supplier can give an idea of how to create pleasant impressions, thereby enhancing customer loyalty. According to the "conceptual model of quality of services with five gaps," what the client considers to be the key attributes of their experience may be completely different from what the service provider believes is already offered as a unique experience (Ghotbabadi, Feiz \& Baharun, 2015). Understanding and exploring the discrepancies between customer perception and the service provider allows hotel and restaurant businesses to fill in these gaps accurately and create the best experience.

\section{Methods}

This research adopts the quantitative research method with a survey data collection technique. A self administered questionnaire (Table 1) has been designed with five point Likert scales and fixed-choice questions to measure attitudes of consumers.

Table1. Self-administered data collection instrument

QUESTIONNAIRE FOR CONSUMERS

Preferences of potential consumers regarding experiences (unique experiences) in the hospitality services sector

\begin{tabular}{|l|l|l|l|l|l|}
\hline & Strongly disagree & Disagree & $\begin{array}{c}\text { Neither agree } \\
\text { nor disagree }\end{array}$ & Agree & $\begin{array}{c}\text { Strongly } \\
\text { agree }\end{array}$ \\
\hline $\begin{array}{l}\text { Kazakhstan should not only provide quality } \\
\text { services, but also create "experience" a } \\
\text { unique value that is accompanied by memo- } \\
\text { rable experiences (for example, provide a } \\
\text { surprise that will exceed your expectations) }\end{array}$ & $\square$ & $\square$ & & \\
\hline $\begin{array}{l}\text { I will be glad to stay at the hotel with the } \\
\text { Soap Butler service (providing natural soap } \\
\text { of your choice) or the Butler by Smell } \\
\text { (providing the opportunity to use the world- } \\
\text { famous perfumes for free) }\end{array}$ & $\square$ & $\square$ & $\square$ & $\square$ & $\square$ \\
\hline $\begin{array}{l}\text { I will be happy to visit the restaurant with } \\
\text { the "Interactive Menu" }\end{array}$ & $\square$ & $\square$ & $\square$ & $\square$ & $\square$ \\
\hline $\begin{array}{l}\text { I will be happy to visit the restaurant, the } \\
\text { fully automated restaurant, where food is } \\
\text { ordered through touch screens, and there are } \\
\text { no attendants }\end{array}$ & $\square$ & $\square$ & $\square$ & $\square$ & $\square$ \\
\hline $\begin{array}{l}\text { I will be happy to stay in a hotel where the } \\
\text { Room Service Robot takes care of you }\end{array}$ & $\square$ & $\square$ & $\square$ & $\square$ & $\square$ \\
\hline $\begin{array}{l}\text { I would prefer to stay not in a classic hotel, } \\
\text { but in hotels with a unique concept (for ex- } \\
\text { ample, thematic hotels, a tree hotel, an un- } \\
\text { derwater hotel, etc.) }\end{array}$ & $\square$ & $\square$ & $\square$ & $\square$ & $\square$ \\
\hline $\begin{array}{l}\text { I will be happy to live in a hotel with a futur- } \\
\text { istic concept, for example, where in the room } \\
\text { you can virtually change the space using } \\
\text { high-tech touch windows }\end{array}$ & $\square$ & $\square$ & $\square$ & $\square$ & $\square$ \\
\hline Note - developed by the authors & & & & $\square$ \\
\hline
\end{tabular}

The data collection process has been divided into 3 continuous stages including 100 (respondents) sample size on each of these stages. Initial data have been collected during the period between August and December, 2019 representing a total sample size of 300 respondents. The sample size is calculated based on 
a size of population comprising economically active population of Kazakhstan with a margin of error $6 \%$ at confidence level of $95 \%$ (Table 2). According to statistics the number of economically active population which is considered as potential consumers amounted to 9.2 million people in the second quarter of 2019 (ZakonKZ, 2019). An optimal sample size for 10 million population lies between 267 and 384 depending on margin of error which is determined between 6\% - 5\% respectively (Saunders et. al, 2019). Due to practical reasons we have increased the sample size from 267 to 300 taking into account the number of potential consumers $(9.2$ million). This quantitative empirical study applied a probability sampling method and involved random distribution technique.

Table 2. Sample size calculation

\begin{tabular}{|l|l|l|}
\hline \multirow{2}{*}{$\begin{array}{l}\text { Population } \\
\text { Size }\end{array}$} & \multicolumn{2}{|l|}{ Confidence Level 95\% } \\
\cline { 2 - 3 } & Margin of Error \% & $\mathbf{5 \%}$ \\
\cline { 2 - 3 } & $\mathbf{6 \%}$ & 278 \\
\hline 1000 & 211 & 322 \\
\hline 2000 & 235 & 357 \\
\hline 5000 & 253 & 370 \\
\hline 10000 & 260 & 383 \\
\hline 100000 & 266 & 384 \\
\hline 1000000 & 267 & 384 \\
\hline 10000000 & 267 & \\
\hline Note - Adopted from Saunders et. al (2019) \\
\hline
\end{tabular}

The response rate of study was 76 percent representing 228 respondents who use the services of restaurants and hotels in Kazakhstan on a permanent basis and defined as potential consumers of hospitality and tourism experiences. The demographic profile showed that these respondents are mainly people of active age who usually take business trips around the country for business purposes.

\section{Results}

Preliminary research findings showed that $50 \%$ of respondents are willing to get more impressions in addition with usual service, which will significantly influence on their memories and will have a deep impact on a customer return. $21.3 \%$ of respondents stayed neutral owing to the fact that they didn't have previously any experiences filled by memorable emotions/impressions. Among the respondents there are those who expressed complete disagreement with additional surprises. But in general, findings indicated that the majority of Kazakhstani consumers of restaurant and hotel services are not opposed to receiving pleasant impressions in the form of unique surprises (memorable experiences) exceeding their expectations.

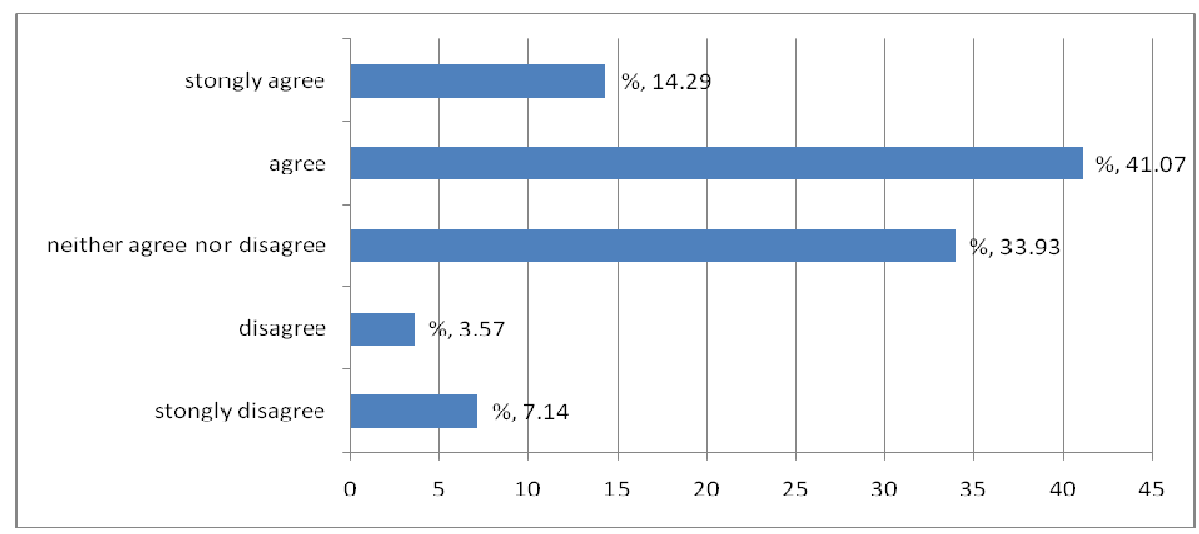

Figure 1: Attitudes of consumers toward "Soap Butler" or "Fragrance Butler" services

Note: Compiled by the authors

The experiential services such as "Soap Butler" or "Fragrance Butler" are not familiar to the majority of Kazakhstani consumers. Only $41.07 \%$ of respondents demonstrate positive attitude towards soap or fragrance butler services, while approximately $34 \%$ of survey participants expressed a neutral opinion, and about $10 \%$ of the respondents are not willing to accept this type of service. 


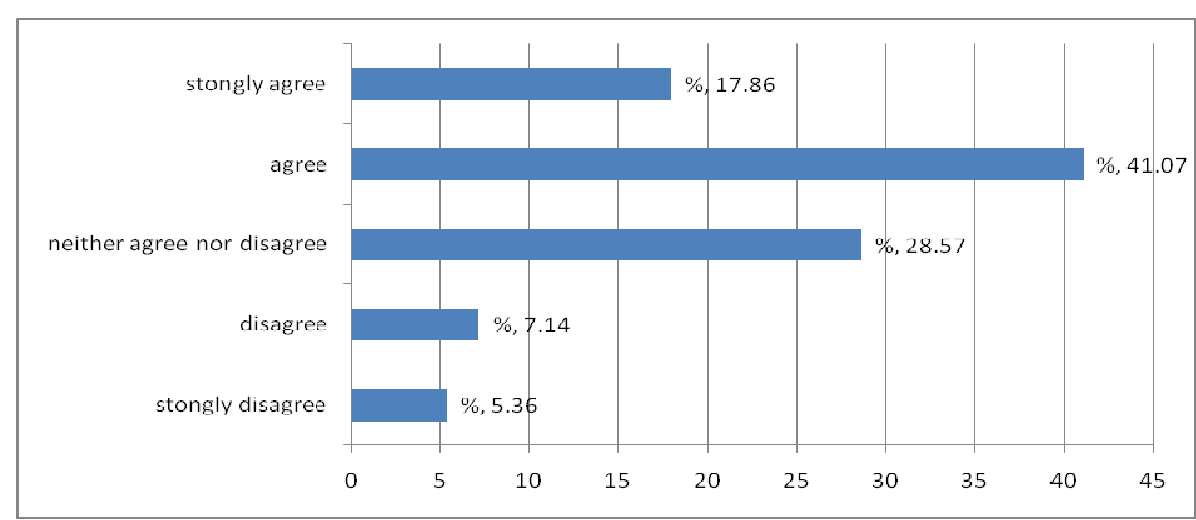

Figure 2: Attitudes of consumers toward "Interactive Restaurant Menu"

Note: Compiled by the authors

In the modern global service industries an increasing attention is paid to innovations and implementation of advanced technological business concepts. For example, the use of the "Interactive menu" is becoming very popular worldwide and this trend is additionally supported by research findings indicating that $41.7 \%$ of respondents have a relatively positive attitude towards advanced restaurant technologies and about $18 \%$ of fully agreed respondents are ready to accept such innovations, while $5.36 \%$ demonstrate a negative attitude towards interactive menu. Approximately $29 \%$ of respondents maintained a neutral opinion on this issue.

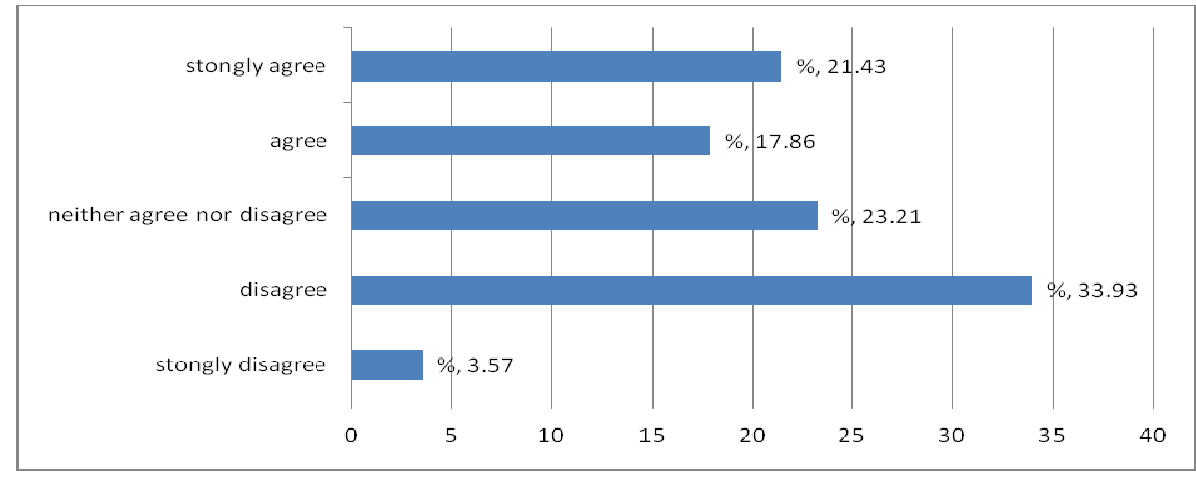

Figure 3: Attitudes of consumers toward fully automated restaurant concepts

Note: Compiled by the authors

Kazakhstani consumers prefer live communication with service personnel more than communication with machines and robots. Findings indicated that $33.94 \%$ of respondents disagreed with the full automation in local restaurants.

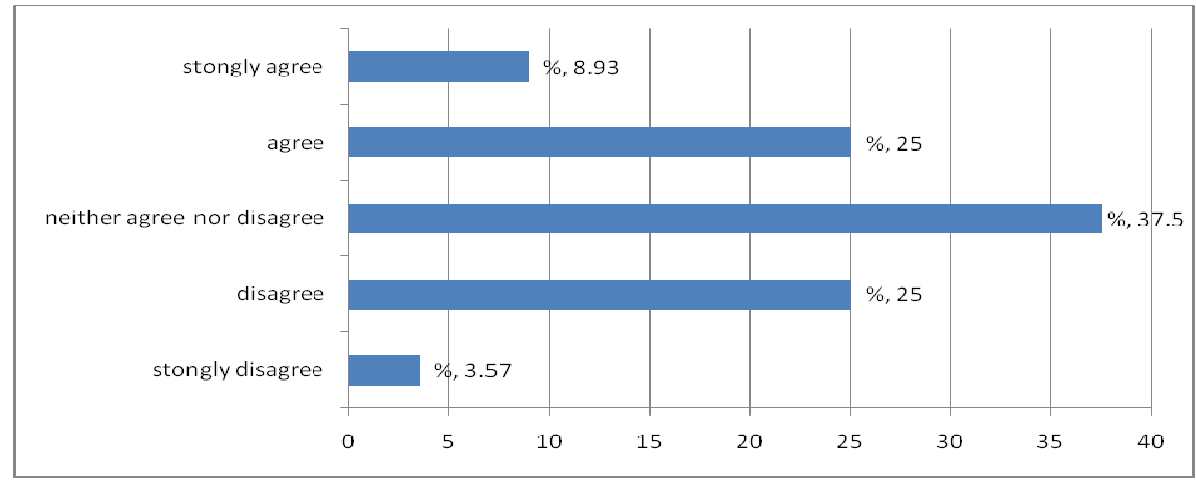

Figure 4: Attitudes of consumers toward robotization of hospitality services 
Robotization today is very important in all spheres including the service sector. The "robot room service" was supported by $25 \%$ of respondents and $9 \%$ fully accept this type of service. On the other hand, $37.50 \%$ of respondents showed a neutral opinion and only $3.57 \%$ of respondents disagree with the robotization of hotel services.

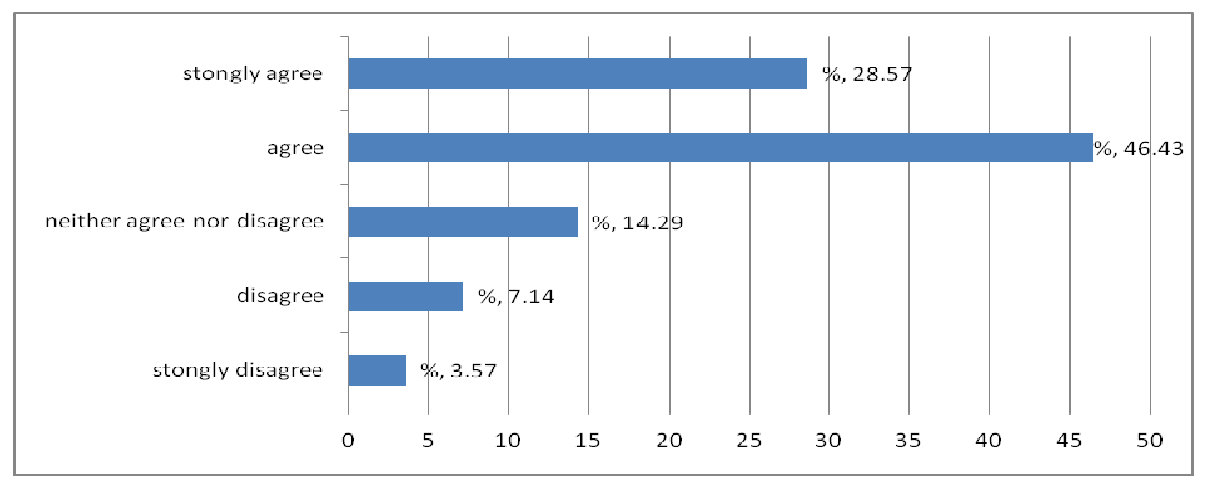

Figure 5: Attitudes of consumers toward staying in hotels with a futuristic concept

Note: Compiled by the authors

Modern sophisticated consumers of hotel services expect services beyond the usual, and hotel industries worldwide are responding to these new emerging trends dictated by changes in consumer behaviour by creating highly differentiated service experiences. Similarly, $46.43 \%$ of Kazakhstani consumers agree to stay in hotels with a futuristic concept, another $28.57 \%$ also support this idea expressing their agreement with the concept, and we see that Kazakhstani consumers are ready for changes in the hotel concepts. Remaining $14.29 \%$ of consumers expressed a neutral opinion, while $3.57 \%$ of respondents disagreed with this concept.

\section{Discussion}

In today's competitive market simply providing higher quality of services is not sufficient. To sustain a competitive advantage (Slatten, Krogh, \& Connolley, 2011) firms need to adopt strategic marketing logic that focuses on a process of designing experiential offerings facilitating positive memories at subconscious level (Lindgreen, Vanhamme, J. \& Beverland, 2012). On the other hand, the competitive advantage is ensured by the right investment strategy, in particular, investment in new technologies. Recent studies showed that the buying behaviour of generation segments (especially $\mathrm{Y}$ and $\mathrm{Z}$ ) is determined by an attitude towards innovative technologies (Kazandzhieva and Filipova, 2019; Aldebert et al., 2010) therefore investing in technology-enhanced experiences might be timely decision for many companies. These investments can be quite expensive for a hotel company, but in case of finding economically efficient ways of implementation can bring great benefits from their use. Enhancing the quality of customer experiences by new technologies will increase the demand for tourism and hospitality services. Moreover, continuous research of a consumer market and the implementation of data analysis systems within the firms will allow domestic companies to better understand the choice of a consumer and as a positive outcome enables to offer more customized service experiences.

We argue that by studying and understanding consumer attitudes and preferences we can understand what kind of memorable experiences will meet the real needs of customers and potential consumers. Furthermore, clear knowledge about attitudes of consumers toward experiential services will facilitate the decision making process of Kazakhstani firms and help to employ efficient customer-oriented strategies, which in turn, transforms the service culture as well as its quality. We found that Kazakhstani consumers have a positive attitude towards service experiences including interactions with advanced technologies (futuristic hotels and interactive menu). Previous studies indicate that transforming regular services into memorable experiences effects positively customer attitudes and significantly influences customer satisfaction and loyalty (Grewall et al. 2019; Foroudi et al., 2018). In this regard, findings of the current study are in line with earlier research and offers additional contributions to existing literature on Kazakhstani context. Furthermore, the research makes an original contribution to the growing body of knowledge from the emerging economies perspective. It also advances fragmented theoretical knowledge investigating the nature and impact of customer experiences through systematic and complex approach to behavioural studies with the detailed focus on various types of experiential services. However, this research has some limitations implying sample size 
and findings that cannot be generalized to specific categories of consumers. In this regard, we suggest future research related to this topic to consider attitudes and behaviours of $\mathrm{Y}$ and $\mathrm{Z}$ generations since they are becoming future growing segments.

\section{Conclusions}

This study provides industrial recommendations and valuable information to hospitality, tourism, marketing and service industries practitioners operating in Kazakhstan as it represents a holistic understanding of modern consumers' attitudes and behaviour. Through its interdisciplinary focus initiating theoretical and practical implications from hospitality, tourism, marketing, and service industries perspectives this research produced the data to facilitate decision making process of service-oriented firms. As can be seen from the survey, modern Kazakh consumers are willing to accept innovative services, and demonstrate positive attitude towards memorable experiences. The study also indicates that local hospitality and tourism market is ready for service innovations and it can be concluded that designing customer-oriented experiences can be an integral part of competitive strategies of hospitality companies and helps to find unique ways to attract modern customer segments.

This research in general provides an insight into changes in consumer attitudes and behaviour within the new experiences-mediated service environment. Moreover, the research expands understanding of the experience economy and fills a contextual as well as theoretical gap by generating holistic knowledge on various forms of customer experiences, simultaneously giving the insight into an emerging Central Asian market represented by the case of Kazakhstan.

\section{References}

Aldebert, B., R. \& Dang, Ch. L. (2010). Innovation in the tourism industry: The case of Tourism. Tourism Management, 32(5), 1204-1213.

Becker, L. \& Jaakkola, E. (2020). Customer experience: fundamental premises and implications for research, Journal of the Academy of Marketing Science, 48, 630-648.

Bharwani, S. \& Jauhari, V. (2013). An exploratory study of competencies required to co-create memorable customer experiences in the hospitality industry, International Journal of Contemporary Hospitality Management, 25 (6), 823-843.

Cetin, G. \& Walls, A. (2015). Understanding the Customer Experiences from the Perspective of Guests and Hotel Managers: Empirical Findings from Luxury Hotels in Istanbul, Turkey, Journal of Hospitality Marketing \& Management, 20: 2, 166-197.

Chen, Ch.-F. \& Chen, F-Sh. (2010). Experience quality, perceived value, satisfaction and behavioral intentions for heritage tourists, Tourism Management, 31, 29-35.

Erdly, M. \& Kesterson-Townes, L. (2003), "Experience rules: a scenario for the hospitality and leisure industry", Strategy \& Leadership, 31(3), 12-18.

Foroudi, P., Gupta, S., Sivarajah, U. \& Broderick, A. (2018). The future of technology and marketing: a multidisciplinary perspective, Journal of the Academy of Marketing Science, 80, 271-282.

Ghotbabadi A.R., Feiz, S. \& Baharun, R. (2015). Service Quality Measurements: A Review, International Journal of Academic Research in Business and Social Sciences, 5(2), 267-286.

Gopalani, A. \& Shick, K. (2011). The service-enabled customer experience: a jump-start to competitive advantage. Journal of Business Strategy, 32(3), 4-12.

Grewal, D., Hulland, J., Kopalle, P.K. \& Karahanna, E. (2019). The future of technology and marketing: a multidisciplinary perspective, Journal of the Academy of Marketing Science, 48, 1-8.

Kandampully J., Zhang T.Ch. \& Jaakkola E. (2017). Customer experience management in hospitality: a literature synthesis, new understanding, and research agenda, International Journal of Contemporary Hospitality Management, $30(1), 21-56$.

Kazandzhieva, V. \& Filipova, H. (2019), Customer Attitudes toward Robots in Travel, Tourism, and Hospitality: A Conceptual Framework, Ivanov, S. and Webster, C. (Ed.) Robots, Artificial Intelligence, and Service Automation in Travel, Tourism and Hospitality, Emerald Publishing Limited, pp. 79-92.

Koutroumanis, D. (2011). Technology's Effect on Hotels and Restaurants: Building a Strategic Competitive Advantage, Journal of Applied Business and Economics, 12(1), 72-80.

Lindgreen, A., Vanhamme, J., \& Beverland, M. (Eds.). (2012). Memorable Customer Experiences: A Research Anthology. Farnham: Gower Publishing.

Meyer, C. \& Schwager, A. (2007). Understanding Customer Experience, Harvard Business Review, 85(2), 116-126.

Pine B. J. \& Gilmore J. H. (1998). Welcome to the experience economy, Harvard Business Review, 76(4), 97-105.

Saunders. M., Lewis, P. \& Thornhill, A. (2019). Research Methods for Business Students, $8^{\text {th }}$ Edition, New York: Pearson. 
Slatten, T., Krogh, C., \& Connolley, S. (2011). Make it memorable: Customer experiences in winter amusement parks. International Journal of Culture, Tourism and Hospitality Research, 5(1), 80-91.

Sparks G. (2016). The Human Experience Imperative. The North Highland Company.

Van Boven, L. \& Gilovich, T. (2003), "To do or to have? That is the question", Journal of Personality and Social Psychology, 85, 1193-1202.

\title{
А.С. Кенебаева, А.И. Нурмагамбетова
}

\section{Туризм және қонақжайлылық индустриясындағы «экспириенс» түрінде ұсынылатын қызметтерге қатысты қазақстандық тұтынушылардың аттитюдтарын талдау}

\begin{abstract}
Аңдатnа
Maқccambl: Мақалада қонақжайлылық және туризм индустриясының қызмет көрсету тұжырымдамасындағы жаңалықтар мен өзгерістер қарастырылған. Зерттеудің мақсаты - Қазақстанның туризм және қонақжайлылық индустриясындағы «экспириенс» түрінде ұсынылатын қызметтерге қатысты қазақстандық тұтынушылардың аттитюдтарын талдау.

Әдісі: Зерттеуде бастапқы деректерді алу барысында сауалнама негізіндегі сандық зерттеу әдісі қолданылған. Бастапқы мәліметтер бес баллдық Лайкерт шкаласын қолдана отырып, алдын ала бекітілген сұрақтардан құрастырылған сауалнама көмегімен жиналды. Бұл сандық эмпирикалық зерттеуде сынаманың ықтималды іріктеу және кездейсоқ бөлу әдістері қолданылған. Сынаманың жалпы саны 300 респондентті құрады.

Қорытынды: Зерттеу нәтижесі қазақстандық тұтынушылардың экспириенстерге, соның ішінде «хош иіске жауапты бөлме қызметшісі», «футуристік қонақ үй» тұжырымдамасы мен «интерактивті ас мәзіріне» қатысты оң көзқараста екендігін көрсетті. Алайда, қазақстандық тұтынушылар роботтармен әрекеттескеннен гөрі қызмет көрсету персоналымен табиғи қарым-қатынасқа түскенді артық санайтындығын және сервисті автоматтандыруға қатысты жағымсыз көзқараста екендігін көрсетті.

Тұжырымдама: Зерттеу нәтижелері отандық қонақжайлылық және туристік нарығының қызмет көрсету саласындағы инновацияларға дайын екендігін көрсетті. Клиентке бағдарланған «экспириенстерді» дамыту жергілікті компаниялардың бәсекеге қабілетті стратегияларының ажырамас бөлігі ретінде қолданыс таба алады және маркетингтің бірегей әдістерін қолдана отырып, заманауи клиенттер сегментін тартуға жол ашады.
\end{abstract}

Кілm сөздер: тұтынушы мінез-құлқы, тұтынушылық аттитюдтар, тұтынушылық артықшылықтар, клиенттік тәжірибе, экспириенс-қызметтер, қызмет көрсету сапасы, қызмет маркетингі, туризм және қонақжайлылық индустриясы.

\section{А.С. Кенебаева, А.И. Нурмагамбетова}

\section{Анализ аттитюдов казахстанских потребителей касательно услуг, предоставляемых в форме экспириенсов в индустрии туризма и гостеприимства}

\section{Аннотация}

Цель: В статье рассмотрены новые изменения в концепции обслуживания клиентов в индустрии туризма и гостеприимства. В частности, целью исследования является изучение отношения и восприятия потребителями новых услуг, предоставляемых в форме экспириенсов в индустрии гостеприимства и туризма Казахстана.

Memoдb: В работе использованы количественные методы исследования с применением анкетирования в качестве сбора первичных данных. Исходные данные были собраны с помощью анкеты, содержащей фиксированные вопросы с использованием пятибалльной шкалы Лайкерта. В данном количественном эмпирическом исследовании применялись методы вероятностной выборки и случайного распределения. Общий объем выборки составил 300 респондентов.

Pезультаты: Результаты показали, что казахстанские потребители положительно относятся к новым концепциям обслуживания и «экспириенсам»- клиентскому опыту, таким как «Мыльный дворецкий», «Футуристические отели» и «Интерактивные меню». Однако казахстанские потребители предпочитают «живое общение» с обслуживающим персоналом, нежели взаимодействие с роботами, и демонстрируют относительно негативное отношение к автоматизации обслуживания.

Bblводы: Как показывают результаты исследования, отечественный рынок гостеприимства и туризма готов к инновациям в сфере услуг. Разработка клиентоориентированных «экспириенсов» может стать неотъемлемой частью конкурентных стратегий местных компаний и будет способствовать привлечению современных клиентских сегментов уникальными маркетинговыми способами. 
Ключевые слова: поведение потребителей, потребительские аттитюды, потребительские предпочтения, клиентский опыт, экспириенс-услуги, качество обслуживания, маркетинг услуг, индустрия туризма и гостеприимства.

\section{References}

Aldebert, B.R. Innovation in the tourism industry: The case of Tourism [Text] / B.R. Aldebert, Ch.L. Dang // Tourism Management. — 2010. — № 32(5). — P. 1204-1213.

Becker, L. Customer experience: fundamental premises and implications for research [Text] / L. Becker, E. Jaakkola // Journal of the Academy of Marketing Science. - 2020. — № 48. - P. 630-648.

Bharwani, S. An exploratory study of competencies required to co-create memorable customer experiences in the hospitality industry [Text] / S. Bharwani, V. Jauhari // International Journal of Contemporary Hospitality Management. - 2013. - № 25(6). - P. 823-843.

Cetin, G. Understanding the Customer Experiences from the Perspective of Guests and Hotel Managers: Empirical Findings from Luxury Hotels in Istanbul, Turkey [Text] / G. Cetin, A. Walls // Journal of Hospitality Marketing \& Management. — 2015. - № 20(2). — P. 166-197.

Chen, Ch.-F. Experience quality, perceived value, satisfaction and behavioral intentions for heritage tourists [Text] / Ch.-F., Chen, F-Sh. Chen //Tourism Management. — 2010. — № 31. — P. 29-35.

Erdly, M. Experience rules: a scenario for the hospitality and leisure industry [Text] / M. Erdly, L. Kesterson-Townes // Strategy and Leadership. — 2003. — № 31(3). — P. 12-18.

Foroudi, P. The future of technology and marketing: a multidisciplinary perspective [Text] / P. Foroudi, S. Gupta, U. Sivarajah, A. Broderick //Journal of the Academy of Marketing Science. — 2018. — № 80. — P. $271-282$.

Foroudi, P. The future of technology and marketing: a multidisciplinary perspective [Text] / P. Foroudi, S. Gupta, U. Sivarajah, A. Broderick //Journal of the Academy of Marketing Science. — 2018. — № 80. — P. $271-282$.

Ghotbabadi A.R. Service Quality Measurements: A Review [Text] / A.R. Ghotbabadi, S. Feiz, R. Baharun // International Journal of Academic Research in Business and Social Sciences. — 2015. — № 5(2). — P. $267-286$.

Gopalani, A. The service-enabled customer experience: a jump-start to competitive advantage [Text] / A. Gopalani, K. Shick //Journal of Business Strategy. — 2011. — № 32(3). — P. 4-12.

Grewal, D. The future of technology and marketing: a multidisciplinary perspective [Text] / D. Grewal, J. Hulland, P.K. Kopalle, E. Karahanna // Journal of the Academy of Marketing Science. — 2019. — № 48. — P. 1-8.

Kandampully J. Customer experience management in hospitality: a literature synthesis, new understanding, and research agenda [Text] / J. Kandampully, T.Ch., Zhang, E. Jaakkola // International Journal of Contemporary Hospitality Management. — 2017. — № 30(1). - P. 21-56.

Kazandzhieva, V. Customer Attitudes toward Robots in Travel, Tourism, and Hospitality: A Conceptual Framework [Text] / S. Ivanov, C. Webster // Robots, Artificial Intelligence, and Service Automation in Travel, Tourism and Hospitality. Emerald Publishing Limited — 2019. — P. 79-92.

Koutroumanis, D.A. Technology's Effect on Hotels and Restaurants: Building a Strategic Competitive Advantage [Text] / D.A. Koutroumanis // Journal of Applied Business and Economics. — 2011. — № 12(1). — P. 72-80.

Lindgreen, A. Memorable Customer Experiences [Text]: a research anthology/ A. Lindgreen, J. Vanhamme, M. Beverland. - Farnham: Gower Publishing, 2012. - 468 p.

Meyer, C. Understanding Customer Experience [Text] / C. Meyer, A. Schwager // Harvard Business Review. — 2007. — № 85(2). - P. 116-126

Pine B.J. Welcome to the experience economy [Text] / B. J. Pine, J. H. Gilmore // Harvard Business Review. — 1998. 一 № 76(4). - P. 97-105.

Saunders, M. Research Methods for Business Students [Text]: a book / M. Saunders, P. Lewis, A. Thornhill. — New York: Pearson, 2019. - 583 p.

Slatten, T. Make it memorable: Customer experiences in winter amusement parks. International Journal of Culture [Text] / T. Slatten, C. Krogh, S. Connolley // Tourism and Hospitality Research. — 2011. — № 5(1). — P. 80-91.

Sparks G. The Human Experience Imperative. The North Highland Company. - 2016.

Van Boven, L. To do or to have? That is the question [Text] / L. Van Boven, T. Gilovich // Journal of Personality and Social Psychology. — 2003. - № 85. - P. 1193-1202. 